\title{
PCA3 wt Allele
}

National Cancer Institute

\section{Source}

National Cancer Institute. PCA3 wt Allele. NCI Thesaurus. Code C92558.

Human PCA3 wild-type allele is located within 9q21-q22 and is approximately $23 \mathrm{~kb}$ in length. This allele, which encodes prostate cancer antigen 3 non-coding RNA, may play a role in prostate carcinogenesis. Aberrant expression is associated with prostate carcinoma. 